\title{
ROLE OF CAREER DEVELOPMENT SERVICES IN DEVELOPING STUDENTS LIFELONG LEARNING SELF-EFFICACY: VOCATIONAL AND ADULT EDUCATION LECTURERS' PERCEPTIONS
}

\author{
James Edomwonyi Edokpolor \\ Benson Idahosa University, Nigeria \\ E-mail: jedokpolor@biu.edu.ng \\ Stella Ebun Omiunu \\ University of Benin, Nigeria \\ E-mail: stellaomiunu@yahoo.com
}

\begin{abstract}
The purpose of this research was to assess the role of career development services in developing student's lifelong learning self-efficacy as perceived by vocational and adult education lecturers. A survey design was employed for the research. A sample of 99 vocational and adult education lecturers from universities and colleges of education in Edo State participated in the research. A structured questionnaire, validated by two experts was used for the collection of data. The Cronbach alpha was used to determine the reliability of instrument, which yielded a coefficient value of.78. Thirty items questionnaire was administered to the respondents by the researchers, with the help of two trained research assistants. The data were analysed using mean, standard deviations and t-test statistics. The findings of the research showed that career development services have a role to play in developing student's lifelong learning self-efficacy. It showed that there was no significant difference between the mean ratings of vocational and adult education lecturers on the role of career development services in developing student's lifelong learning self-efficacy. These findings showed that vocational and adult education lecturers have the same perception on the role of career development services in developing student's lifelong learning self-efficacy. It was therefore recommended, among others, that government through curriculum designers should integrate career development services into vocational and adult education programmes. This would help to instil confidence and positive attitude on students and working adults so that they can continuously learn new skills that would stimulate them for lifelong learning activities. Keywords: career development services, lifelong learning, work environment, student's self-efficacy.
\end{abstract}

\section{Introduction}

It is generally agreed that vocational and adult education have become the most viable education programmes for the development of human resources and national economy. To lead a useful, productive, and satisfying life in any society, one should be involved in vocational and adult education throughout life. This is because vocational and adult education has been seen as a crucial tool to help in adjusting to a constantly changing environment and overcoming socio-economic problems, 
such as: the increasing rate of unemployment and level of poverty. As such, vocational and adult education may be regarded as skills-oriented education for life and life for skills-oriented education. For instance, the United Nations Educational, Scientific and Cultural Organization (2013) remarked that vocational education and training is not just about preparation for the world of work, but for life, and this is why, it is so important to make it accessible to all. Vocational and adult education, therefore, does not only mean learning through formal education alone, but falls within the scope of formal, non-formal, and informal education; and the learning process that helps to combine these three forms of education can be regarded as lifelong learning.

Nowadays, government policies across the globe are focusing on the systemic approaches to lifelong learning. In all, Norway has been recognized as one of the country which had a broad support for the integration of lifelong learning. The Organization for Economic Co-operation and Development (OECD) (2002) pointed out that lifelong learning is a system-wide approach that embraces education and training at all levels, such as: formal, non-formal, and informal learning. The definition used by the European Commission is one of the most widely accepted definitions among researchers and policy makers, as: "all learning activities undertaken throughout life, with the aim of improving knowledge, skills, and competence within a personal, civic, social, and/or employment related perspective" (European Commission, 2001, p. 9). Earlier research have also argued that lifelong learning is an empirical reality, not a political strategy, in that adults learn throughout the developmental stages of adulthood in response to life crises, for the innate joy of learning, and for specific task purposes (Brookfield, 1983a). Also, McMahon, Patton and Tatham (2008) in the Australian Blueprint for Career Development (ABCD) contend that the objectives of lifelong learning are to ensure that initial education and training provides a sound foundation for further learning and that opportunities for learning in adulthood are available to everyone.

The effort to promote continuous learning (or lifelong learning in general) is basically sparked by the labour-market concerns, in ensuring that workers are flexible enough to retain or regain their jobs and the right of individuals for personal development and enrichment. Today, the labour market concern in Nigeria has attracted the bulk of tensions and discussions. The basic issue is how the world of learning can be linked with the world of work. The gap between the world of learning and the world of work appeared to be responsible for the increasing rates of unemployment and underemployment in Nigeria. Today, the rate of unemployment has increased from $13.3 \%$ in second quarter of 2016 to $13.9 \%$ in third quarter of 2016 , while underemployment has increased from $19.3 \%$ in second quarter of 2015 to $19.7 \%$ in third quarter of 2016 (National Bureau of Statistics, 2016). Using an earlier report, about $50 \%$ of Nigerians between ages of 15 and 24, and living in urban areas, were unemployed in $2009,17.3 \%$ of those in the age group of 25 to 44 were unemployed in the same year, while $10 \%$ of those in the age group of 45 to 59 , and living in the urban areas were unemployed in the same year (NBS, 2011). These statistics have shown that unemployment rate is higher among youths. Due to the high rate of unemployment in recent years, policy makers believed that lifelong learning is beneficial in particular to those who are affected by unemployment, restructuring, and career transitions (European Council, 2011).

Based on this situation, a person has to form a positive attitude or favourable attitudes, which has help him or her to become a lifelong learner, and to successfully plan and manage his or her career (Patton \& McMahon, 1999; Augiene, 2015). Within the context of lifelong learning, Law, Meijers and Wijers (2002) remind us that our focus on learning in a rapidly changing world needs to be related to skills and competencies, as well as focus on how students learn (process), not on what they learn (content). The Association for Career and Technical Education (ACTE) (2008) further tells us that the $21^{\text {st }}$ century workplace is changing rapidly, in that the traditional method of educational delivery are no longer sufficient to equip students with the attributes to navigate the complex work environment. As a result, students now need educational programmes that integrate strong career development services that would provide the support and guidance necessary to connect them to hopes, dreams and realities of their future. Along these perspectives, McMahon, et al., (2008, p. 9) pointed out that "as individuals are being challenged to accept greater responsibility for constructing their own careers across the lifespan, a greater imperative exists for career development services to assist them in navigating the complexity of the world of work". The European Commission (2001) in its Memorandum on Lifelong Learning emphasized that the goals of career development services 
are to ensure that every person could easily access high quality information and advice related to lifelong learning and professional activity opportunities. As such, the important role of career development services in promoting lifelong learning has long been predicted by Hackett (1995), when she reported that, in today's rapidly changing world of work, the need for career services is likely to increase. Watts (1999) further argued that there are both social and economic benefits to be gained from the integration of such services, as students are assisted to derive maximum benefit from their education, training, and employment choices, and as such economic competitiveness is improved through a better placed, more motivated, and productive workforce. The ACTE (2008) also stressed that the provision of career development services throughout life would not only lead to an individual success, but also ensure a better informed and prepared citizenry to meet the social, economic and workforce needs. In this respect, providing access to continuous learning, ensuring capacity to acquire knowledge and skills, and creating opportunity to continuously updating one's cognitive, social, and creative skills over the lifespan, is the key, not only to economic development, but also to student's career development and social cohesion.

In vocational and adult education curricula, career development interventions need to be given a pride of place in order to help in developing the need and interest of students for lifelong learning. In fact, there has been an increasing outcry on educational reform, over the years, and a growing emphasis on career development interventions as a part of educational reform (Drier \& Ciccone, 1988; Gysbers, 1992; Herr, 1992; Gysbers \& Henderson, 2000). In this clarion call, teachers should first have a tendency for lifelong learning in order to pass it on to their students (Coolahan, 2002: Chang, Wu \& Lin, 2012). It is important for teachers to continuously learn new skills so as to cope with the rapidly changing world of work (Diehm \& Lupton, 2014). Teachers can then help students to develop confidence to learn throughout life. In this context, ensuring student's lifelong learning self-efficacy may further contribute to career development processes.

The term 'career' can be defined as individual's lifelong progression both in learning and in work (Leong, 2012), while the term 'development' in its psychological sense refers to certain changes that occur in humans (or animals) between conception and death (Woolfolk, 2014). Therefore, career development can be viewed as the process of managing learning and work over the lifespan (Patton, 2001). Baer, Flexer, Luft and Simons (2008) claim that career development is a lifetime process that encompasses the growth and change process of childhood, formal career education at school, and the maturation processes that continue throughout a person's working adulthood into retirement. Sears cited in Patton and McMahon (2014) remarked that it is the total constellation of psychological, sociological, educational, physical, economic and chance factors that combine to shape the career of individuals over the lifespan. Accordingly, the OECD career guidance policy report has conceptually clarified the meaning of career development services as:

...services intended to assist people, of any age and at any point throughout their lives to make educational, training and occupational choices and manage their careers. Career development helps people to reflect on their ambitions, interests, qualifications and abilities. It helps them to understand the labour market and education systems, and to relate this to what they know about themselves. Comprehensive career development tries to teach people to plan and make decisions about work and learning. Career development makes information about the labour market and about educational opportunities more accessible by organizing it, systematizing it, and making it available when and where people need it (OECD, 2004, p.19).

An alternative definition further proposed that career development services can be defined as a: ...dialogic, mutually pedagogical relationship, that serves in conscientizing individuals and groups about the social forces that define the world of work and that affect the range of opportunities available to them, while at the same time equipping them with the political skills, networks, community resources, values, and dispositions to struggle for social and work arrangements that are equitable and just, where one's development and self-fulfilment advances the development and fulfilment of others (Sultana, 2017, p. 11).

The first definition showed that career development services help to guide clients in accessing employment opportunities and involving them in planned and systematic learning activities between entrance and retirement. The latter definition takes a much more proactive stance in encouraging a persons' 'capacity to aspire' (Appadurai, 2004), conscientizing them in ways that help them move beyond their 'bounded rationality' (Simon, 1991), their 'adaptive preferences' (Biggeri, 2010; 
Nussbaum, 2001), their 'horizons for career activities' (Hodkinson., Sparkes, \& Hodkinson, 1996; Hodkinson \& Sparkes, 1997), and promoting advocacy as well as community mobilization so that career development services truly become a force, among others, championing economic and social justice (Sultana, 2017). Krumboltz and Worthington (1999, p. 313) also agreed with these broad definitions when they acknowledged that career development services is an educative process and a process of learning that facilitates "the learning of skills, interests, beliefs, values, work habits, and personal qualities that enable each client to create a satisfying life within a constantly changing work environment". Career development services can therefore be seen as strategies that include expectations that people will value work and learning, plan, be purposeful, be productive, and be serious about life's meaning (Herr \& Niles, 1994).

It has often been pointed out that there are three main elements of career development services, namely: career information services, career counselling services, and career education services (OECD, 2004; Watts \& Fretwell, 2004; Watts, 2009; Watts, 2013). These services have been acknowledged as a major propellant or contributor to lifelong learning (OECD, 1998a; European Commission, 2001; National Research Center for Career and Technical Education, 2003; Guichard, 2005; European Centre for the Development of Vocational Training, 2008). For instance, career information may be seen as all the information necessary to plan for, or obtain employment and educational activities and ensure stability. The International Labour Organization (ILO) (2006) stipulated that career information includes, but not limited to information on occupations, skills, career paths, learning opportunities, labour market conditions, educational programmes and opportunities, educational and training institutions, government and non-governmental programmes and services, as well as, employment or work opportunities.

Herr and Cramer (1996) viewed career counselling largely as a verbal process in which a counsellor and counselees are in a dynamic and collaborative relationship, focused on identifying the counselee's goals. At this point, the counsellor employs a repertoire of diverse techniques and processes, to help in bringing about self-understanding, understanding of behavioural options available and informed decision-making in the counselee, who has the responsibility for his or her own actions. The ILO (2006) opined that career counselling helps people to clarify their aims and aspirations, understand their own identity, make informed decisions and commit to action, and manage career transitions both planned and unplanned. Wright (1997) conveyed the function of career counselling as a means of helping clients to explore their own thoughts and feelings about their present situation, about options open to them, and about the consequences of each option. This means that the role of career counselling is not just to help clients to acquire the skills required to deal with change, but first to help them to discover what skills and knowledge are needed and then help them to determine how, where and when they can be acquired and also how to implement them in a proactive and well-planned manner (van Esbroeck, 2002). The main goal of career counselling, therefore, is to help clients make informed decisions and transit them towards career success. The knowledge provided during career counselling is expected to instil in the clients a range of competencies, including abilities to assess their own personal qualities, skills, needs, interests, attitudes and values and seek and sort information about opportunities in education, training, and work. It also helps to match personal information with information about opportunities, and show ability to select and use appropriate decision-making strategy to choose between opportunities; use an actionplanning process to achieve goals; use self-presentation skills in a selection process and cope with transition from one learning environment to another.

The Education Bureau (2014) defined career education as the development of knowledge and skills through a systematic and planned programme of learning experiences in education and training settings which will assist students in making informed decisions about their study and/or work options and enable effective participation in working life. The ILO (2006) argued that it is delivered in the educational institutions and sometimes in community organizations by teachers, career guardians or counsellors and community resource persons. It helps students to understand their motives, their values and how they might contribute to societal development. It provides students with the knowledge of labour market; skills to make educational, life and work choices; opportunities to experience community service and working life; and tools to plan a career path. Broadly speaking, Lamanauskas and Augienè (2017, p. 217) averred that career education helps: 
... the pupil to cognize his own professional calling, personal ability, interest, gift correspondence with the chosen professional field, to acquire career planning and management skill, helping to create and implement career plans, corresponding to personality peculiarities, to accumulate necessary knowledge and skills for implementing them, to flexibly react to society and labour market changes, to be able to successfully make proper, career related decisions, to acquire lifelong learning motivation, successfully settle in the changing labour market, solve personal life questions.

With the above clarifications, career services seem to be relevant in stimulating student's confidence so that they can continuously learn new skills throughout life. Yet, career services in Nigeria today are relatively inactive in the education sector and are still on a trial-and-error basis (Amalaha, 2017). Providing opportunity for students to acquire skills that are compatible with their intrinsic abilities can potentially play an important role in instilling confidence so that they can continuously learn new skills over the lifespan (Igbinedion, Edokpolor \& Oyenuga, 2015). The level of student's confidence in their abilities to successfully perform future tasks is referred to as self-efficacy. Selfefficacy can be defined as client's level of beliefs about their capabilities to successfully carry out courses of action, perform given behaviours, accomplish given tasks, and attain desired performance outcomes (Bandura, 1977, 1993, 1997; Buchmann, 1997; Betz \& Hackett, 1981; Betz \& Taylor, 2001; Lent., Brown, Hackett, 1994; Nesdale \& Pinter, 2000). This may explain why Bandura's (1986) model of social learning viewed self-efficacy as a cognitive structure created by cumulative learning experiences in a person's life. Self-efficacy beliefs determine how people feel, think, behave and motivate them-selves. It represents the extent to which people believe that they are the authors of what they do and can have an impact on what happens to them (Schwarzer, 1992; Schwarzer \& Jerusalem, 1995; Scholz, Gutierrez Dona, Sud, \& Schwarzer, 2002; Cervone, Artisitco, \& Berry, 2006). Consequently, the applied concept of self-efficacy in continuous formal and informal learning activities can be referred to as lifelong learning self-efficacy. In this context, lifelong learning selfefficacy can be described as the acquisition of cognitive attributes that stimulates people to continuously pursue formal and informal learning activities over the lifespan. This implies that the increased use of meaningful career services may help in encouraging student's lifelong learning self-efficacy. As such, the consistent relationship between career services and lifelong learning self-efficacy is very crucial in an era of uncertainty and economic turmoil. This is why McMahon, et al., (2008, p, 9) noted that: "as individuals are being challenged to accept greater responsibility for constructing their careers across the lifespan, a greater imperative exists for career development services to assist them to navigate the complexity of the world of work". Hence, to sustain employability, students need to be prepared to continuously learn new skills in response to the changing world of work.

In Japan, Yamao and Moriyama (2012) investigated the influence of students' career maturity in job self-efficacy in technical high schools. In the same country, Yamao, Moriyama, Shimada, Ichihara, Nakahara, Miyagawa and Uenosono (2014) studied the influence of career development on promoting students' job self-efficacy in technical high schools. In Korea, Park and Yang (2014) conducted a study on the relationship between career decision-making styles and job seeking selfefficacy of college students. Surprisingly, there is little or no research investigation regarding the role of career development services in developing student's lifelong learning efficacy. In this research, the authors choose to assess the role of career development services in developing student's lifelong learning self-efficacy as perceived by vocational and adult education lecturers in universities and colleges of education in Edo State, Nigeria.

The research further proceeds by first providing a factual explanation on what prompted the authors to embark on the research. This is followed by an explanation of the methods and procedures that show how the research was conducted. The analyses of research questions and testable hypotheses are then presented. Next, the major findings from the data analysed are also discussed. Finally, the authors drew a logical conclusion based on the findings of the research.

\section{Problem of the Research}

The rapid technological and societal developments, together with forces of globalization have led to some dramatic changes in the world of work. These ongoing developments across the globe appear to be making jobs and skills obsolete overnight. Unfortunately, many employers of labour 
and owners of businesses have long discovered that employees are not prepared well-enough and lack basic skills (Holton \& Trott, 1996). The result from a recently conducted field research further suggests that the reason behind this gap is that there is inadequacy in terms of capacity to engage in lifelong learning (Global e-Schools and Communities Initiative, 2013). These challenges require teachers, students and schools to be responsive, and thus regularly review their careers and continuously redevelop themselves (learn new skills) and their practices (Nicholls, 2001; Darling-Hammond, 2006). To remain competitive, teachers and students need to engage in lifelong learning so as to update their education and work skills (Dede, 2007; OECD, 2009). Responsiveness to these challenges is particularly relevant for vocational and adult education programmes. This is because vocational and adult education programmes are in the forefront in seeking new approaches to preparing their students for lifelong learning activities of the future. One area of concern that vocational and adult education programmes in Nigeria must integrate into their curriculum contents are career development services. It is based on this situation that the authors embarked on this research in order to provide empirical data on the role of career development services on the development of student's lifelong learning self-efficacy.

The main purpose of this research, therefore, was to assess the role of career development services in developing student's lifelong learning self-efficacy as perceived by vocational and adult education lecturers. Hence, the following questions were put forward to guide the research:

1. What is the role of career information services in developing student's lifelong learning self-efficacy as perceived by vocational and adult education lecturers?

2. What is the role of career counselling services in developing student's lifelong learning self-efficacy as perceived by vocational and adult education lecturers?

3. What is the role of career education services in developing student's lifelong learning self-efficacy as perceived by vocational and adult education lecturers?

\section{Methodology of Research}

\section{General Background of the Research}

The design that has been used in this research is a quantitative approach or technique, by employing a survey research design. The central purpose of a survey research is to describe the characteristics of a population (Fraenkel \& Wallen, 2006). It is primarily a quantitative research technique in which the researcher administers some sort of questionnaire to a sample or, in some cases, entire populations of individuals in order to describe their attitudes, opinions, behaviours, experiences, or other characteristics of the population (Creswell, 2005). Therefore, survey design was appropriate for this research in that it helps the researchers to collect data from vocational and adult education lecturers in order to determine their perceptions on the role of career development services in developing student's lifelong learning self-efficacy. The vocational and adult education lecturers were selected from universities and colleges of education in Edo State. The research specifically covers the role of career information, career counselling, and career education services in developing student's lifelong learning self-efficacy as perceived by vocational and adult education lecturers. It was further conducted in the 2016/2017 academic session.

\section{Sample of the Research}

There was no need to adopt any sampling technique, nor select any sample size for the research because the population is of a manageable size (Jack \& Jelly, 2005). Glenn (2009) recommended that at Precision level of $\pm 3 \%$ for population of $\leq 1,000$, all of them should be used. Based on this assertion, the entire population was used, which comprised of 96 out of 99 vocational and adult education lecturers from both universities and colleges of education in Edo State (Source: Departmental Record Office of the Universities and Colleges of Education 2016/2017 Academic Year). 
Baltic Journal of Career Education and Management

\section{Instrument and Procedure}

The instrument for data collection was a survey questionnaire titled: "Questionnaire on the Role of Career Development Services in Developing Student's Lifelong Learning Self-Efficacy (QRCDSDSLLS)". Bryman (2007) opined that questionnaire is an appropriate instrument for collecting quantitative data. The questionnaire items were validated using three experts from vocational and technical education, measurement and evaluation, and adult and non-formal education respectively. The final copies of their corrected items were reproduced for answering of research questions and testing of null hypotheses at 0.05 level of significance. A reliability coefficient value of .71 was obtained, using the internal consistency method, by applying Cronbach's alpha formula. Thirty (30) items questionnaire were further administered to respondents by the researchers, with the help of two trained research assistants.

\section{Data Analysis}

The data collected from the respondents were analysed using mean, standard deviations and t-test statistics. The mean was used to answer the research questions, while the t-test was used to test the hypotheses at .05 level of significant. The standard deviations were used to determine the extent to which the responses were clustered to or deviated from the mean responses. The decision rule for the research questions was based on any calculate mean equal to, or greater than 2.50 is regarded as agree; while any calculated mean less than 2.50 is regarded as disagree. Also, any standard deviation value between .00 and .96 shows that vocational and adult education lecturer's responses are very close. Furthermore, the value (p) was used in taking the decisions on the hypotheses. If the p-value is less than or equal to .05 , the null hypotheses is rejected, but if the p-value is greater than .05 , the null hypotheses is retained.

\section{Results of the Research}

The data collected from the respondents were analysed using the Mean () and Standard Deviation (SD) and the results are presented in Tables 1 to 3 .

\section{Table 1: Mean and standard deviation of the role of career information services in developing student's lifelong learning self-efficacy as perceived by vocational and adult education lecturers.}

\begin{tabular}{|c|c|c|c|c|}
\hline $\mathrm{S} / \mathrm{N}$ & Statements & $\bar{X}$ & SD & Remarks \\
\hline 1. & $\begin{array}{l}\text { Help students to find information they need, so that they can confidently pursue } \\
\text { their course of choice in life. }\end{array}$ & 3.77 & .492 & Agree \\
\hline 2. & $\begin{array}{l}\text { Provide students with information to assess their abilities and personality styles, so } \\
\text { that they can confidently pursue their course of choice in life. }\end{array}$ & 3.70 & .545 & $"$ \\
\hline 3. & $\begin{array}{l}\text { Provide students with information to explore exciting possibilities, so that they can } \\
\text { confidently make continuous learning decisions. }\end{array}$ & 3.65 & .542 & $"$ \\
\hline 4. & $\begin{array}{l}\text { Provide students with information to understand what they have to accomplish in a } \\
\text { course, so that they can confidently pursue the same course of choice in life. }\end{array}$ & 3.59 & .591 & $"$ \\
\hline 5. & $\begin{array}{l}\text { Provide students with general overview of information they need, so that they can } \\
\text { confidently pursue their course of choice in life. }\end{array}$ & 3.50 & .632 & $"$ \\
\hline 6. & $\begin{array}{l}\text { Provide students with information to foster growth of career skills and planning } \\
\text { awareness, so that they can confidently make lifelong learning decisions. }\end{array}$ & 3.52 & .580 & $"$ \\
\hline 7. & $\begin{array}{l}\text { Provide students with information to understand education systems, so that they } \\
\text { can confidently pursue courses that are compactable with their abilities, values, } \\
\text { interests and personality styles in life. }\end{array}$ & 3.51 & .598 & $"$ \\
\hline 8. & $\begin{array}{l}\text { Provide students with information about education, so that they can confidently } \\
\text { seize and pursue any opportunity available to them. }\end{array}$ & 3.49 & .649 & $"$ \\
\hline
\end{tabular}




\begin{tabular}{clccc}
\hline S/N & \multicolumn{1}{c}{ Statements } & $\bar{X}$ & SD & Remarks \\
\hline 9. & $\begin{array}{l}\text { Help to address information deficits that act as barriers to students, so that they } \\
\text { would have access to any learning opportunities available to them. }\end{array}$ & 3.43 & .611 & " \\
10. & $\begin{array}{l}\text { Help to maximize human capital (knowledge and skills) of client's, so that they can } \\
\text { confidently pursue educational career paths in life. }\end{array}$ & 3.50 & .580 \\
\hline
\end{tabular}

Table 1 shows the mean responses of vocational and adult education lecturer perceptions on the role of career information services in developing student's lifelong learning self-efficacy. The result revealed that 10 items had the mean scores that range from 3.43 to 3.77, while the corresponding standard deviation values ranged from .492 to .649 respectively. These simply imply that career information services can play an important role in developing student's lifelong learning self-efficacy, while the corresponding standard deviation values simply imply that vocational and adult education lecturer perceptions on the role of career information services in developing student's lifelong learning self-efficacy are very close irrespective of their different disciplines.

Table 2: Mean and standard deviation on the role of career counselling services in developing student's lifelong learning self-efficacy as perceived by vocational and adult education lecturers.

\begin{tabular}{|c|c|c|c|c|}
\hline$S / N$ & Statements & $\bar{X}$ & SD & Remarks \\
\hline 11. & $\begin{array}{l}\text { Help students to gain greater awareness of their abilities and personality styles, } \\
\text { so that they can confidently pursue educational careers they are compactable } \\
\text { with in life. }\end{array}$ & 3.58 & .556 & Agree \\
\hline 12. & $\begin{array}{l}\text { Help in connecting students to resources, so that they can be knowledgeable } \\
\text { about or aware of relevant courses so that they can confidently pursue them in } \\
\text { life. }\end{array}$ & 3.54 & .597 & $"$ \\
\hline 13. & $\begin{array}{l}\text { Help in engaging students in decision-making processes, so that they can } \\
\text { confidently choose courses that are compactable with their abilities and } \\
\text { personality styles. }\end{array}$ & 3.42 & .574 & " \\
\hline 14. & $\begin{array}{l}\text { Help students to become active managers of educational transitions, so that } \\
\text { they can confidently pursue educational careers that are compatible with their } \\
\text { personality styles, interests, values and abilities. }\end{array}$ & 3.46 & .614 & $"$ \\
\hline 15. & $\begin{array}{l}\text { Help students with appropriate advice, so that they would become lifelong } \\
\text { learners in the sense of career development practice over the lifespan. }\end{array}$ & 3.46 & .579 & " \\
\hline 16. & $\begin{array}{l}\text { Help students to make meaningful choices about their direction of study and to } \\
\text { ensure that they are given every opportunity to succeed in life. }\end{array}$ & 3.41 & .591 & " \\
\hline 17. & $\begin{array}{l}\text { Help to widen access to learning by group of students who are under-confident } \\
\text { in, or unskilled in negotiating complex learning systems. }\end{array}$ & 3.32 & .571 & " \\
\hline 18. & $\begin{array}{l}\text { Help students to make brilliant (informed) decisions, so that they can confidently } \\
\text { make right educational choices throughout life. }\end{array}$ & 3.39 & .569 & $"$ \\
\hline
\end{tabular}

Table 2 shows the mean responses of vocational and adult education lecturer perceptions on the role of career counselling services in developing student's lifelong learning self-efficacy. The result revealed that 10 items had the mean scores that range from 3.32 to 3.58 , while the corresponding standard deviation values ranged from .556 to .614 respectively. These simply imply that career counselling services can play an important role in developing student's lifelong learning self-efficacy, while the corresponding standard deviation values simply imply that vocational and adult education lecturer perceptions regarding the role of career counselling services in developing student's lifelong learning self-efficacy are very close irrespective of their different institutions. 
Baltic Journal of Career Education and Management

38

Table 3: Mean and standard deviation on the role of career education services in developing student's lifelong learning self-efficacy as perceived by vocational and adult education lecturers.

\begin{tabular}{|c|c|c|c|c|}
\hline$S / N$ & Statements & $\bar{X}$ & SD & Remarks \\
\hline 19. & $\begin{array}{l}\text { Provide students with knowledge to identify their personality styles, interests, } \\
\text { abilities and gain understanding of the world of learning, so that they can } \\
\text { confidently pursue their course of choice in life. }\end{array}$ & 3.44 & .539 & Agree \\
\hline 20. & $\begin{array}{l}\text { Help students to reflect on their ambitions and qualifications, so that they can } \\
\text { confidently pursue educational careers they are suited for in life. }\end{array}$ & 3.43 & .594 & " \\
\hline 21. & $\begin{array}{l}\text { Help stimulate students' confidence about performing tasks that are related to } \\
\text { lifelong learning exploration. }\end{array}$ & 3.43 & .645 & " \\
\hline 22. & $\begin{array}{l}\text { Help to bridge the gap between students' skills and lifelong learning, so that they } \\
\text { can continuously learn current issues in life. }\end{array}$ & 3.47 & .561 & $"$ \\
\hline 23. & $\begin{array}{l}\text { Provide students with skills and competencies to learn about the wide-range of } \\
\text { educational options available to them, so that they can confidently pursue their } \\
\text { course of choice in life. }\end{array}$ & 3.42 & .592 & $"$ \\
\hline 24. & $\begin{array}{l}\text { Help in developing student's skills and competencies that would reconcile } \\
\text { educational entry requirements with their interests, abilities, aptitudes, and } \\
\text { values. }\end{array}$ & 3.40 & .607 & " \\
\hline 25. & $\begin{array}{l}\text { Help students to learn how to make realistic and informed course choices } \\
\text { through their exposure to real-life experiences. }\end{array}$ & 3.44 & .595 & $"$ \\
\hline 26. & $\begin{array}{l}\text { Help equip students with competencies and sellable skills necessary to enter } \\
\text { and succeed in other educational institutions. }\end{array}$ & 3.34 & .595 & " \\
\hline 27. & $\begin{array}{l}\text { Help group of students to develop kills and competencies, so that they can } \\
\text { confidently manage their educational choices in life. }\end{array}$ & 3.41 & .555 & $"$ \\
\hline 28. & $\begin{array}{l}\text { Help students to link education and labour market by introducing better systems } \\
\text { for translating labour market signals into educational choices. }\end{array}$ & 3.45 & .540 & $"$ \\
\hline 29. & $\begin{array}{l}\text { Provide students the opportunity to experience community service and working } \\
\text { life, so that they can confidently pursue course of choice in life. }\end{array}$ & 3.44 & .558 & $"$ \\
\hline 30. & $\begin{array}{l}\text { Provide students with tools to plan educational career paths, so that they can } \\
\text { confidently pursue them over the lifespan }\end{array}$ & 3.49 & .580 & $"$ \\
\hline
\end{tabular}

Table 3 shows the mean responses of vocational and adult education lecturers perceptions on the role of career counselling services in developing student's lifelong learning self-efficacy. The result revealed that 10 items had the mean scores that range from 3.32 to 3.58 , while the corresponding standard deviation values ranged from .556 to .614 respectively. These simply imply that career counselling services can play an important role in developing student's lifelong learning self-efficacy, while the corresponding standard deviation values simply imply that vocational and adult education lecturer perceptions regarding the role of career counselling services in developing student's lifelong learning self-efficacy are very close irrespective of their gender differences.

Hypothesis 1: There is no significant difference between the perceptions of vocational and adult education lecturers on the role of career information services in developing student's lifelong learning self-efficacy. 
Table 4: t-test analysis between the perceptions of vocational and adult education lecturers on the role of career information services in developing student's lifelong learning self-efficacy.

\begin{tabular}{|c|c|c|c|c|c|c|c|c|}
\hline \multirow{2}{*}{ Variable } & \multirow{2}{*}{ Respondents } & \multirow[b]{2}{*}{$\mathbf{N}$} & \multicolumn{2}{|c|}{ Aggregate } & \multirow[b]{2}{*}{ df } & \multirow[b]{2}{*}{$\mathrm{t}$} & \multirow[b]{2}{*}{$p$} & \multirow{2}{*}{ Decision } \\
\hline & & & Mean & SD & & & & \\
\hline \multirow[t]{3}{*}{$\begin{array}{l}\text { Career information services } \\
\text { and student's lifelong learning } \\
\text { self-efficacy }\end{array}$} & Vocational Educators & 81 & 3.55 & .493 & 94 & .911 & .364 & NR \\
\hline & Adult Educators & 15 & 3.67 & .282 & & & & \\
\hline & Total & 96 & & & & & & \\
\hline
\end{tabular}

Source: Field Study, 2016 NR: Not Rejected

The results presented in table 4 revealed that the aggregate mean responses of vocational and adult education lecturers on the role of career information services in developing student's lifelong learning self-efficacy are 3.55 and 3.67, while the corresponding standard deviation values are .493 and .282 respectively. The Table also showed that the t-value is .911 at $\mathrm{df}$ of 94 , while the p-value (.364) is greater than the alpha value (.05), therefore, the null hypothesis is retained. Hence, there is no significant difference between the perceptions of vocational and adult education lecturers on the role of career information services in developing student's lifelong learning self-efficacy.

Hypothesis 2: There is no significant difference between the perceptions of lecturers in universities and colleges of education on the role of career counselling services in developing student's lifelong learning self-efficacy.

Table 5: $\quad$ t-test analysis between the perceptions of lecturers in universities and colleges of education on the role of career counselling services in developing student's lifelong learning self-efficacy.

\begin{tabular}{|c|c|c|c|c|c|c|c|c|}
\hline \multirow{2}{*}{ Variable } & \multirow{2}{*}{ Respondents } & \multirow[b]{2}{*}{$\mathbf{N}$} & \multicolumn{2}{|c|}{ Aggregate } & \multirow[b]{2}{*}{ df } & \multirow[b]{2}{*}{$\mathbf{t}$} & \multirow[b]{2}{*}{$p$} & \multirow{2}{*}{ Decision } \\
\hline & & & Mean & SD & & & & \\
\hline \multirow[t]{3}{*}{$\begin{array}{l}\text { Career counselling services } \\
\text { and student's lifelong learning } \\
\text { self-efficacy }\end{array}$} & Universities & 55 & 3.46 & .519 & 94 & .258 & .797 & NR \\
\hline & Colleges of Education & 41 & 3.43 & .328 & & & & \\
\hline & Total & 96 & & & & & & \\
\hline
\end{tabular}

Source: Field Study, 2016

NR: Not Rejected

The results presented in table 5 revealed that the aggregate mean responses of lecturers in universities and colleges of education on the role of career counselling services in developing student's lifelong learning self-efficacy are 3.46 and 3.28, while the corresponding standard deviation values are .517 and .328 respectively. The Table also showed that the t-value is .258 at df of 94 , while the p-value (.797) is greater than the alpha value (.05), therefore, the null hypothesis is retained. Hence, there is no significant difference between the perceptions of lecturers in universities and colleges of education on the role of career counselling services in developing student's lifelong learning selfefficacy.

Hypothesis 3: There is no significant difference between the perceptions of male and female lecturers on the role of career education services in developing student's lifelong learning self-efficacy. 


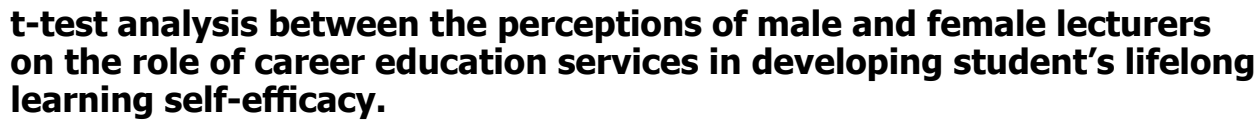

\begin{tabular}{|c|c|c|c|c|c|c|c|c|}
\hline \multirow{2}{*}{ Variable } & \multirow{2}{*}{ Respondents } & \multirow{2}{*}{$\mathbf{N}$} & \multicolumn{2}{|c|}{ Aggregate } & \multirow[b]{2}{*}{ df } & \multirow[b]{2}{*}{$t$} & \multirow[b]{2}{*}{$p$} & \multirow{2}{*}{ Decision } \\
\hline & & & Mean & SD & & & & \\
\hline \multirow[t]{3}{*}{$\begin{array}{l}\text { Career education services and } \\
\text { student's lifelong learning self- } \\
\text { efficacy }\end{array}$} & Male & 49 & 3.45 & .368 & 94 & .616 & .539 & $N R$ \\
\hline & Female & 47 & 3.39 & .502 & & & & \\
\hline & Total & 96 & & & & & & \\
\hline
\end{tabular}

Source: Field Study, 2016

NR: Not Rejected

The results presented in table 4 revealed that the aggregate mean responses of male and female lecturers on the role of career education services in developing student's lifelong learning self-efficacy are 3.45 and 3.39, while the corresponding standard deviation values are .368 and .502 respectively. The Table also showed that the t-value is .616 at $\mathrm{df}$ of 94 , while the p-value (.539) is greater than the alpha value (.05), therefore, the null hypothesis is retained. Hence, there is no significant difference between the perceptions of male and female lecturers on the role of career education services in developing student's lifelong learning self-efficacy.

\section{Discussion}

The research has assessed the role of career development services in developing student's lifelong learning self-efficacy as perceived by vocational and adult education lecturers. It specifically investigates the role of career information, career counselling, and career education services in developing student's lifelong learning self-efficacy as perceived by vocational and adult education lecturers. It can be inferred from the result of the research that career information services have a great role to play in developing student's lifelong learning self-efficacy. This is an important finding for scholars and educators particularly in the field of vocational and adult education, because career information services have been seen as all the information necessary to plan for, or obtain employment and educational activities and ensure stability. The OECD (2004) stipulated that career information services help to provide information about labour market and about educational opportunities more accessible by organizing it, systematizing it, and making it available when and where people need it. Igbinedion, Edokpolor and Oyenuga (2015) noted that providing opportunity for students to acquire information that is compatible with their intrinsic abilities can potentially play a role in instilling self-confidence and positive attitude so that they can continuously learn new skills over the lifespan.

The second finding in this research is that career counselling services have a potential role to play in developing student's lifelong learning self-efficacy. This finding conforms with the view of Idowu and Adeoye (1990) who has long acknowledged that career counseling services is a process of planned intervention within a school system by which the total development of students is stimulated in areas relating to their personal, social, career, emotional and academic concerns. The ILO (2006) also stated that career counseling services help people to clarify their aims and aspirations, understand their own identity, make informed decisions and commit to action, and manage career transitions both planned and unplanned. Wright (1997) conveyed the function of career counseling as a means of helping students to explore their own thoughts and feelings about their present situation, about options open to them, and about the consequences of each option. This means that the role of career counseling is not just to help clients to acquire the skills required to deal with change, but first to help them to discover what skills and knowledge are needed and then help them to determine how, where and when they can be acquired and also how to implement them in a proactive and in a well-planned manner (van Esbroeck, 2002).

The third and last finding in this research is that career education services have a potential role to 
play in developing student's lifelong learning self-efficacy. This finding corroborates with the view of Lamanauskas and Augienè (2017) who broadly asserted that career education helps the pupil to cognize his own professional calling, personal ability, interest, gift correspondence with the chosen profession field, to acquire career planning and management skills helping to create and implement career plans, corresponding to personality peculiarities, to accumulate necessary knowledge and skills for implementing them, to flexibly react to society and labour market changes, to be able successfully make proper, career related decisions, to acquire lifelong learning motivation, successfully settle in the changing labour market, to solve personal life questions. They established in their research that career education has the greatest importance on students' professional decision formation and professional decision demand. They also argued that career actualization demand is important, because it helps the students to understand career importance, encourages students of low motivation to be interested in lifelong learning career. Also, Parsons (1909) have supported the idea that career development interventions can promote student academic growth by addressing problems such as low expectations and self-doubts.

\section{Limitations of the Research}

There is no research that can be completely devoid of limitations. This research is, therefore, not without limitations, although it has provided some concrete and useful empirical evidence as regards the important role of career development services in developing student's lifelong learning self-efficacy as perceived by vocational and adult education lecturers from both university and colleges of education in Edo State, Nigeria. First, the research participants are distinct, and of relatively small size. So, caution should be exercised in generalizing the research findings to other fields of research. Second, this study employed a descriptive survey design, which does not ultimately allow causal inference to be made in any study. The researchers, therefore, recommend that longitudinal or experimental research can be conducted in future for better results. Finally, there is no doubt that people may not be better assessors of their strengths and weaknesses; hence there may be insincere responses by the respondents of this research.

\section{Conclusions and Recommendations}

This research investigated the role of career development services in developing student's lifelong learning self-efficacy as perceived by vocational and adult education lecturers from both university and colleges of education in Edo State, Nigeria. The emergence of the global economy as well as technological innovations informed the need to embark on this research. The ongoing changes in our society and in the world of work are making jobs and skills obsolete overnight. The implication is that vocational and adult education teachers and students in particular would have to engage in continuous or lifelong learning in order to be able to update their education and job skills. The research therefore concluded that the effective provision and utilization of career development services or the provision and utilization of high profile career development services has a great role to play in instilling self-confidence and positive attitude on vocational and adult education students so that they can continuously learn new skills over the lifespan. Based on the aforementioned findings of the research, it is, therefore, recommended that:

1. Government should endeavour to integrate career development services into vocational and adult education curriculum in order to provide opportunity for students to acquire skills that are compatible with their intrinsic abilities, and indeed help in instilling selfconfidence on them so that they can continuously learn new skills over the lifespan.

2. Managers and leaders of vocational and adult education programmes should endeavour to ensure the effectiveness of career development services in order to equip students with the skills to successfully settle in the constantly changing labour market.

3. Teachers and instructors should endeavour to engage in continuous or lifelong learning in order to be able to update their education and job skills. This will then help them to cope with the rapidly changing work environment. This would further help in orienting their students towards the usefulness of lifelong learning activities. 


\section{References}

Amalaha, M. C. (2017). The impact of the economic recession on the educational guidance system: Experience from Nigeria. A Paper Presented at the $10^{\text {th }}$ Annual International Conference of the Delta State University. Abraka.

Appadurai, A. (2004). The capacity to aspire: Culture and the terms of recognition. In V. Rao \& M. Walton (Eds.), Culture and public action. Palo Alto, CA: Stanford University Press.

Association for Career and Technical Education (2008). Career and Technical Education's Role in Career Guidance. Issue Brief. Retrieved from https://www.acteonline.org/WorkArea/DownloadAsset.aspx?id=2095.

Augienè, D. (2015). Lifelong learning as a successful career condition. Baltic Journal of Career Education and Management, 3 (1), 4-6. Retrieved from http://oaji.net/articles/2016/453-1471935556.pdf

Baer, R. B., Flexer, R. W., Luft, P., \& Simons, T. J. (2008). Transition planning for secondary students with disabilities. New Jersey. Pearson Education Inc.

Bandura, A. (1977). Self-efficacy: Toward a unifying theory of behavioral change. Psychological Review, 84 (2), 191-215. Retrieved from https://www.uky.edu/ eushe2/Bandura/Bandura1977PR.pdf.

Bandura, A. (1986). Social foundations of thought and action: A social cognitive theory. Englewood Cliffs, NJ: Prentice-Hall.

Bandura, A. (1993). Perceived self-efficacy in cognitive development and functioning. Educational Psychologist, 28 (2), 117-148. Retrieved from https://www.uky.edu/ eushe2/Bandura/Bandura1993EP.pdf.

Bandura, A. (1997). Self-efficacy: The exercise of control. New York, NY: W.H. Freeman and Co.

Betz, N. E., \& Hackett, G. (1981). The relationship of career-related self-efficacy expectations to perceived career options in college women and men. Journal of Counseling Psychology, 28 (5), 399-410.

Betz, N. E., \& Taylor, K. M. (2001). Manual for the career decision self-efficacy scale and CDMSE-Short Form.

Biggeri, M. (2010). Children's valued capabilities. In M. Walker \& E. Unterhalter (Eds.), Amartya Sen's capability approach and social justice in education. Basingstoke: Palgrave Macmillan.

Brookfield, S. D. (1983a). Adult learners, adult educator, and the community. Milton Keynes, England: Open University Press.

Bryman, A. (2007). Qualitative data analysis. London, UK: SAGE Publications.

Buchmann, W. F. (1997). Adherence: a matter of self-efficacy and power. Journal of Advanced Nursing, 26 (1), 132-137.

Cervone, Artisitco \& Berry (2006). Self-efficacy and adult development. In C. Hoare (Ed.). Handbook of adult development and learning. New York.

Chang, D. F., Wu, M. L., \& Lin, S. P. (2012). Adults engaged in lifelong learning in Taiwan: Analysis by gender and socio-economic status. Australian Journal of Adult Learning, 52 (2), 310-335.

Coolahan, J. (2002). Teacher education and the teaching career in an era of lifelong learning. The OECD Education Working Papers, No. 2, OECD Publishing. Retrieved from http://files.eric.ed.gov/fulltext/ ED503820.pdf.

Creswell, J. W. (2005). Educational research: Planning, conducting, and evaluating quantitative and qualitative research $\left(2^{\text {nd }} E d\right)$. Upper Saddle River, NJ: Merrill/Prentice Hall.

Darling-Hammond, L. (2006). Constructing $21^{\text {st }}$ century teacher education. Journal of Teacher Education, 57 (10), 1-15. Retrieved from http://citeseerx.ist.psu.edu/viewdoc/download?doi=10.1.1.453.1099\&rep= rep1\&type=pdf.

Dede, C. (2007). Transforming education for the $21^{\text {st }}$ century: New pedagogies that help all students attain sophisticated learning outcomes. Commissioned by the NCSU Friday Institute, Harvard University.

Diehm, R. \& Lupton, M. (2014). Learning Information Literacy. Information Research, 19 (1). Retrieved from http://eprints.qut.edu.au/68639/1/68639.pdf.

Drier, H. N. \& Ciccone, J. K. (1988). Career guidance: The missing link in educational excellence and work transition. Journal of Career Development, 15 (1), 3-12.

Education Bureau (2014). Guide on life planning education and career guidance for secondary schools. Career Guidance Section School Development Division, Education Bureau. 
European Centre for the Development of Vocational Training (2008). Establishing and developing national lifelong guidance policy forums: A manual for policy-makers and stakeholders. Luxembourg: Office for Official Publications of the European Communities.

European Commission (2001). A Memorandum on Lifelong Learning. Commission Staff Working Paper. Brussels. Retrieved from http://arhiv.acs.si/dokumenti/Memorandum_on_Lifelong_Learning.pdf.

European Commission (2001). Making a European area of lifelong learning a reality. Brussels, Belgium: Commission of the European Communities.

European Council (2011). Council resolution on a renewed European agenda for adult learning. Official Journal of the European Union, C372: 1-6. Retrieved from http://www.basicskills.eu/wp-content/uploads/2013/08/Council-Resolution.pdf.

Fraenkel, J. R. \& Wallen, N. E. (2006). How to design and evaluate research in education ( $6^{\text {th }}$ Ed). Boston: McGraw-Hill.

Glenn, D. I. (2009). Determining sample size. University of Florida, IFAS Extension, PEOD6.

Global e-Schools and Communities Initiative (2013). Development of 21st century skills for innovation and enterprise: Exploring the role of Informal learning environments in the development of skills and aptitudes for the digital creative media industries. Retrieved from http://gesci.org/fileadmin/user_upload/2_Youth_Skills_Enterprise_Files/AKE_research_-_21C_Skills_Full_Report_-_2012_.pdf.

Guichard, J. (2005). Life-long self-construction. International Journal for Educational and Vocational Guidance, 5 (2), 111-124.

Gysbers, N. C. (1992). The comprehensive guidance programme model. In Walz, G. R. (Ed.). Counseling and guidance in the schools: Three exemplary guidance approaches. Reference \& resource series (9-24). Washington, DC: National Education Association.

Gysbers, N. C. \& Henderson, P. (2000). Developing and managing your school guidance programme. Alexandria, VA: American Counseling Association.

Hackett, G. (1995). Self-efficacy in career choice and development. In A. Bandura (Ed.). Self-efficacy in Changing Societies. United Kingdom, Cambridge University Press. Retrieved from http://catdir.loc. gov/catdir/samples/cam034/94049049.pdf.

Herr, E. L. (1992). Emerging trends in career counseling. Special Section: Counseling and health concerns. International Journal for the Advancement of Counseling, 15 (4), 255-288.

Herr, E. L. \& Cramer, S. H. (1996). Career guidance and counseling through the life span. New York, Longman.

Herr, E. L. \& Niles, S. G. (1994). Multicultural career guidance in the schools. In P. Pedersen \& J. C. Carey (Eds.). Multicultural counseling in schools: A practical handbook. Needham Heights, Massachusetts: Allyn and Bacon.

Hodkinson, P., \& Sparkes, A. C. (1997). Careership: A sociological theory of career decision making. British Journal of Sociology of Education, 18 (1), 29-44.

Hodkinson, P., Sparkes, A. C. \& Hodkinson, H. (1996). Triumphs and tears: Young people, markets and the transition from school to work, London: David Fulton.

Holton, E. F. \& Trott, J. W. (1996). Trends toward a closer integration of vocational education and human resource development. Journal of Vocational and Technical Education, 12 (2). Retrieved from http:// files.eric.ed.gov/fulltext/EJ527004.pdf.

Idowu, A. I. \& Adeoye, E. A. (1990). Guidance and counseling in the National Policy on Education: A revisit. The Counselor: Journal of the Counseling Association of Nigeria, 10 (1), 101-109.

Igbinedion, V. I., Edokpolor, J. E. \& Oyenuga, A. O. (2015). Trends towards a closer integration of vocational education and career guidance in Nigeria. The Vocational and Applied Science Journal (TVASJ), 12, 48-63.

International Labour Organization (ILO) (2006). Career Guidance: A Resource Handbook for Low-and Middle-Income Countries. International Labour Office (ILO), Geneva. Retrieved from https://www. uhr.se/globalassets/syv/webbibliotek/utbildning-och arbetsliv/career_guidance.pdf.

Jack, K. N., \& Jelly, K. T. (2005). Research methods in physical activities. Chicago: Human Kinetics Campaign Report, 62-81.

Krumboltz, J. D., \& Worthington, R. J. (1999). The school to work transition from a learning theory perspective. The Career Development Quarterly, 47 (4), 312-325. 
Lamanauskas, V., \& Augienè, D. (2017). Career education in comprehensive schools of Lithuania: Career professionals` position. In A. Klim-Klimaszewska, M. Podhajecka, \& A. Fijalkowska-Mroczek (Eds.). Orientacje i przedsiewziecia w edukacjiprzedszkolnej i szkolnej /Monografia/ (pp. 216-236). Siedlce: Akka.

Law, B., Meijers, F., \& Wijers, G. (2002). New perspectives on career and identity in the contemporary world. British Journal of Guidance and Counseling, 30 (4), 431-449.

Lent, R. W., Brown, S. D., Hackett, G. (1994). Toward a unifying social cognitive theory of career and academic interest, choice, and performance. Journal of Vocational Behavior, 45 (1), 79-122.

Leong, S. (2012). Incorporating career development learning in a business work integrated learning framework. Retrieved from http://acen.edu.au/2012conference/wp-content/uploads/2012/11/122_Incorporatingcareer-development-learning-in-a-business-work-integrated-learning-framework.pdf.

McMahon., M. Patton., W. \& Tatham, P. (2008). Managing life, learning and work in the 21st Century: Issues informing the design of an Australian Blueprint for Career Development. Australian Blueprint for Career Development. Miles Morgan Australia Pty Ltd.

National Bureau of Statistics (NBS) (2011). 2011 Annual Socio-Economic Report. Retrieved from www. nigerianstat.gov.ng/download/38.

National Bureau of Statistics (NBS) (2016). Unemployment and under-employment watch: First quarter of 2016. Retrieved from www.nigerianstat.gov.ng/download/397.

National Research Center for Career and Technical Education (2003). Career development interventions and academic self-efficacy and motivation: A pilot study. Retrieved from https://s3.amazonaws.com/NCICTE/ pdf/career_dev_dykeman.pdf.

Nesdale, D. \& Pinter, K. (2000). Self-efficacy and job-seeking activities in unemployed ethnic youth. Journal of Social Psychology, 140 (5), 608-614.

Nicholls, G. (2001). Professional development in higher education: New dimensions and directions. Sterling: Stylus Publishing Inc.

Nussbaum, M. (2001). Adaptive preferences and women's options. Economics and Philosophy, 17, 67-88.

Organization for Economic Cooperation and Development (OECD) (2002). Reviews of national policies for education: Lifelong learning in Norway. Paris, France: OECD.

Organization for Economic Co-operation and Development (OECD) (2004). Career Guidance and Public Policy: Bridging the Gap. Paris: OECD. Retrieved from http://www.oecd.org/edu/innovation-education/34050171.pdf.

Organization for Economic Co-operation and Development (OECD) (1998a). Recurrent education: Adults engaged in lifelong learning. Australian Journal of Adult Learning, 52 (2), 310-336.

Organization for Economic Co-operation and Development (OECD) (2009). $21^{\text {st }}$ century skills and competences for new millennium learners in OECD countries. Paris: OECD Publishing. Retrieved from http://www. oecd.org/officialdocuments/publicdisplaydocumentpdf/?cote=edu/wkp(2009)20\&doclanguage=en.

Patton, W. (2001). Career education: What we know, what we need to know. Australian Journal of Career Development, 10 (3), 13-19.

Patton, W., \& McMahon, M. (1999). Career development and systems theory: A new relationship. Pacific Grove, CA: Brooks/Cole.

Patton, W., \& McMahon, M. (2014). Career development and systems theory: Connecting theory and practice ( $3^{\text {rd }}$ Ed.). Netherlands, Sense Publishers.

Park, M. H., \& Yang, K. S. (2014). The relationship between career decision-making styles and job seeking self-efficacy of college students in Korea. Journal of Asian Vocational Education and Training, 7, 3239. Retrieved from http://www.javet.net/wp-content/uploads/2015/05/4_2014JAVET_Volume7_Parkpp32-39.pdf.

Parsons, F. (1909). Choosing a vocation. Boston: Houghton Mifflin.

Scholz, U., Gutierrez., D. B., Sud, S., \& Schwarzer, R. (2002). Is general self-efficacy a universal construct? Psychometric findings from 25 countries. European Journal of Psychological Assessment, 18 (3), 241-252.

Schwarzer, R. (Ed.). (1992). Self-efficacy: Thought control of action. Washington, DC: Hemisphere. 
Schwarzer, R., \& Jerusalem, M. (1995). Generalized self-efficacy scale. In J. Weinman, S. Wright, \& M. Johnston (Eds.). Measures in health psychology: A user's portfolio. Causal and control beliefs, 35-37, Wind-sor: NFER-Nelson.

Simon, H. (1991). Bounded rationality and organizational learning. Organization Science, 2 (1), 125-134.

Sultana, R. G. (2017). Anchoring career guidance in the Mediterranean? In search of southern perspectives. In R. G. Sultana (Ed.). Career guidance and livelihood planning across the Mediterranean: Challenging transitions in South Europe and the MENA Region. Rotterdam, The Netherlands: Sense Publishers. Retrieved from https://www.sensepublishers.com/media/3168-career-guidance-and-livelihood-planningacross-the-mediterranean.pdf.

United Nations Educational, Scientific and Cultural Organization (UNESCO) (2013). Shanghai Update, Issue No. 1, June 2013. Bonn: UNESCO-UNEVOC. Retrieved from http://www.unesco.org/new/fileadmin/ MULTIMEDIA/HQ/ED/pdf/shanghaiupdateJune2013.pdf.

Van Esbroeck, R. (2002). Career guidance and counseling for lifelong learning in a global economy. In UNESCO. Technical and vocational education and training in the twenty-first century: New roles and challenges for guidance and counseling. Retrieved from http://unesdoc.unesco.org/images/0013/001310/131005e.pdf.

Watts, A. G. (1999). The economic and social benefits of career guidance. Unpublished manuscript. Cambridge, UK: NICEC.

Watts, A. G. (2009). The relationship of career guidance to vocational education and training. Organization for Economic Co-operation and Development (OECD). Paris. Retrieved from http://www.oecd.org/edu/ skills-beyond-school/44246616.pdf.

Watts, A. G. (2013). Career Guidance and Orientation. In the United Nations Educational, Scientific and Cultural Organization (UNESCO). Revisiting Global Trends in TVET: Reflections on Theory and Practice. UN Campus. Germany. Retrieved from http://www.unevoc.unesco.org/fileadmin/up/2013_epub_revisiting_global_trends_in_tvet_book.pdf

Watts, A. G., \& Fretwell, D. (2004). Public policies for career development: Case studies and emerging issues for designing career information and guidance systems in developing and transition economies, Discussion Paper (World Bank, Washington), March. 2004. Retrieved from http://citeseerx.ist.psu.edu/ viewdoc/download?doi $=10.1 .1 .548 .135 \&$ rep $=$ rep $1 \&$ type $=$ pdf

Woolfolk, A. (2014). Educational psychology (12 $2^{\text {th }}$ Ed.). United States: Pearson Education Ltd.

Wright, S. (1997). Career and vocational education. In H. Mason \& S. McCall (Eds.). Visual impairment: Access to education for children and young people. London: David Fulton

Yamao, H., \& Moriyama, J. (2012). Influences on students' career maturity in their job self-efficacy in technical high schools. Journal of the Japan Society of Technology Education, 54 (2), 95-101.

Yamao, H., Moriyama, J., Shimada, Ichihara, K., Nakahara, Y., Miyagawa H., \& Uenosono (2014). Effects of career guidance on promoting students' job self-efficacy in technical high school: A longitudinal case study in Japan. Journal of Asian Vocational Education and Training, 7, 14-21. Retrieved from http:// www.javet.net/wp-content/uploads/2015/05/2_2014JAVET_Volume7_Yamao-pp14-21.pdf. 